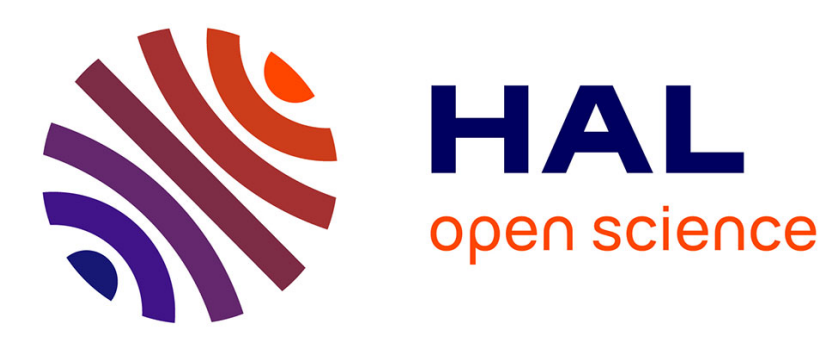

\title{
Novel signals mediating the functions of somatostatin: The emerging role of NO/cGMP
}

Kyriaki Thermos

\section{To cite this version:}

Kyriaki Thermos. Novel signals mediating the functions of somatostatin: The emerging role of NO/cGMP. Molecular and Cellular Endocrinology, 2008, 286 (1-2), pp.49. 10.1016/j.mce.2008.02.008 . hal-00532001

\section{HAL Id: hal-00532001 \\ https://hal.science/hal-00532001}

Submitted on 4 Nov 2010

HAL is a multi-disciplinary open access archive for the deposit and dissemination of scientific research documents, whether they are published or not. The documents may come from teaching and research institutions in France or abroad, or from public or private research centers.
L'archive ouverte pluridisciplinaire $\mathbf{H A L}$, est destinée au dépôt et à la diffusion de documents scientifiques de niveau recherche, publiés ou non, émanant des établissements d'enseignement et de recherche français ou étrangers, des laboratoires publics ou privés. 


\section{Accepted Manuscript}

Title: Novel signals mediating the functions of somatostatin:

The emerging role of NO/cGMP

Author: Kyriaki Thermos

PII: $\quad$ S0303-7207(08)00069-5

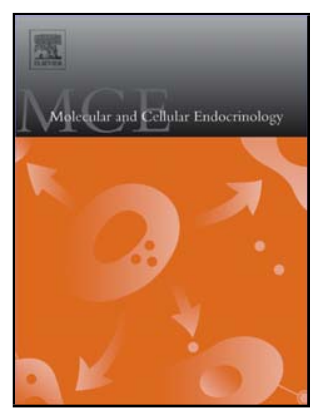

DOI: doi:10.1016/j.mce.2008.02.008

Reference: MCE 6820

To appear in: Molecular and Cellular Endocrinology

Received date: 24-7-2007

Revised date: 11-2-2008

Accepted date: $12-2-2008$

Please cite this article as: Thermos, K., Novel signals mediating the functions of somatostatin: The emerging role of NO/cGMP, Molecular and Cellular Endocrinology (2007), doi:10.1016/j.mce.2008.02.008

This is a PDF file of an unedited manuscript that has been accepted for publication. As a service to our customers we are providing this early version of the manuscript. The manuscript will undergo copyediting, typesetting, and review of the resulting proof before it is published in its final form. Please note that during the production process errors may be discovered which could affect the content, and all legal disclaimers that apply to the journal pertain. 
NOVEL SIGNALS MEDIATING THE FUNCTIONS OF SOMATOSTATIN:

THE EMERGING ROLE OF NO/cGMP

Kyriaki Thermos

University of Crete, Faculty of Medicine, Department of Basic Sciences,

Laboratory of Pharmacology, Heraklion, Crete 71110 GR

Tel: +302810394533

Fax: +302810394530

Email: thermos@med.uoc.gr 


\begin{abstract}
The neuropeptide somatostatin is a cyclic tetradecapeptide, which is widely distributed in the peripheral and central nervous system. It mediates a plethora of physiological actions and functions as a neurotransmitter, neuromodulator or trophic factor. Somatostatin activates six receptor subtypes that are expressed differentially in different tissues and are coupled to diverse signalling pathways. In order to elucidate the functional role of the individual receptor subtypes, many investigations focused on the assignment of each receptor to a particular signalling pathway. Signalling pathways involving enzyme (adenylate cyclase, phospholipases, phosphatases) and ion channel systems in native and recombinant receptor systems have been extensively studied. A one to one situation (receptor/pathway) has yet to be established, thus justifying the diverse actions of somatostatin. Recently, a NO/cGMP pathway has been shown to mediate the functions of somatostatin and its receptors. This review will present the findings that support the emerging role of NO/cGMP as a novel signal in SRIF's actions in retinal physiology and somatotroph release.
\end{abstract}

Key words: Somatostatin, nitric oxide, cGMP, retina, somatotrophs 


\section{Contents}

1. Introduction

2. Nitric oxide/cGMP as a signalling mechanism for somatostatin

2.1 Nitric oxide physiology

2.2 Somatostatin-NO Interactions

2.2.1. Retinal physiology

2.2.2 GH Regulation

3. NO/cGMP as mediators of the neuroprotective effects of somatostatin

4. Conclusions

Acknowledgements

References

\section{Introduction}

The neuropeptide somatostatin (somatotropin release inhibitory factor, SRIF) is a cyclic tetradecapeptide, which is widely distributed in the peripheral and central nervous system (Brazeau et al., 1973). It mediates a diverse number of physiological actions by interacting with specific receptors in the plasma membrane (Thermos and Reisine, 1988; Thermos et al., 1989, Olias et al., 2004). Five SRIF receptor subtypes have been cloned, namely sst $t_{1-5}$, with the $\mathrm{sst}_{2}$ to exist as two-splice variants $\mathrm{sst}_{2 \mathrm{~A}}$ and sst $_{2 B}$ (Olias et al., 2004; for nomenclature see Hoyer et al., 1995).

The cloning of the receptors promoted the development of specific SRIF ligands, agonists and antagonists (Rohrer et al., 1998; Bass et al., 1996; Reubi et al., 2000; Hoyer et al., 2004; Tulipano et al., 2002), specific antibodies (Schulz et al., 2000) and genetically modified mice (Kreienkamp et al., 1999; Viollet et al., 2000; Allen et al., 2003; Strowski et al., 2003) that aided our understanding of the signalling pathways 
involved in SRIF's multiple actions. These receptors are expressed differentially in different tissues, coupled to diverse intracellular pathways and mediate SRIF's plethora of actions in physiological systems and disease states.

An extensive number of studies and a number of reviews (Reisine and Bell, 1995; Patel 1999; Tannenbaum and Epelbaum, 2000; Csaba and Dournaud, 2001; Olias et al., 2004) have addressed the intracellular signalling pathways responsible for SRIF's diverse actions. The results obtained were mostly from studies performed in cell lines transfected with the recombinant receptors, but also in native systems. While one must be cautious in interpreting the different results obtained from the transfected cell lines, one cannot but acknowledge the significance of this work in pinpointing specific roles for each receptor subtype.

Initially characterized for its adenylyl cyclase and pertussis toxin sensitive actions (Mahy et al., 1988), SRIF is now known to activate many other effector systems, including phospholipase A2, phospholipase C, and different phosphatases (Moller et al., 2003; Olias et al., 2004). In addition, activation of the receptors leads to the regulation of ion channels, affecting potassium and calcium currents (Meriney et al., 1994; Tallent et al., 1996; Akopian et al., 2000).

In the last decade, a number of reports have suggested an emerging new pathway involving nitric oxide (NO)/cGMP to be involved in SRIF's actions. In the literature, there is a large number of studies supporting the colocalization of SRIF with nitric oxide synthase (NOS) or NADPH-diaphorase (a marker for NOS, Dawson et al., 1991) in brain and the periphery. To give a few examples, SRIF is colocalized a) with NADPH-diaphorase in medium sized aspiny neurons of the striatum (Vincent and Johansson, 1983, Dawson et al., 1991), b) in nNOS/GABAergic neurons in the cortex (Kubota et al., 1994, Higo et al., 2007) and c) in NOS neurons of the human gall 
bladder (Uemura et al., 1997). However, in these cited studies there are no data to suggest that the two colocalized systems, namely SRIF and NO interact functionally to modulate each other's synthesis and/or release and their subsequent respective physiological actions.

In contrast, there are examples depicting the colocalization of ssts and NOS and/or NADPH-diaphorase which suggest that activation of the receptors by SRIF will influence the synthesis of NO and subsequent signalling molecules (cGMP) that may play a critical role in SRIF's actions (Vasilaki et al., 2001, 2004, Mastrodimou et al., 2006b). This review will focus on data from retinal physiology and somatotroph release studies that substantiate the importance of SRIF/sst/NO/cGMP signalling.

\section{NO/cGMP as a signalling mechanism for somatostatin}

\subsection{Nitric oxide physiology}

NO is produced by the activation of NOS which oxidizes the guanidine moiety of L-arginine to liberate NO and citrulline (Bredt and Snyder, 1992). Three different isoforms of NOS have been characterized. The neuronal (nNOS) and endothelial (eNOS) NOS are dependent on $\mathrm{Ca}^{++} /$calmodulin and are constitutively expressed. They are regulated by alternate mRNA splicing, protein-protein interactions and covalent modifications (phosphorylation, myristoylation, palmitoylation). The third isoform of the enzyme, the inducible NOS (iNOS), is induced upon stimulation of cytokines and other proinflammatory agents in a wide variety of cells (Nathan and Xie, 1994, Alderton et al., 2001).

NO is synthesized in a large number of tissues and displays diverse physiological actions, including smooth muscle contractility, platelet reactivity, central and peripheral neurotransmission. NO mediates its actions by activating a soluble 
guanylyl cyclase (GC; Koesling et al., 2004), which converts GTP to cGMP after the binding of NO to the prosthetic hemegroup of the enzyme (Koesling et al., 2004; Wedel et al., 1994). cGMP has important functions, as an intracellular signalling molecule, in the regulation of various cellular events. Cyclic GMP exerts its effects through cGMP-dependent protein kinases, cGMP-dependent phosphodiesterases and cGMP-regulated ion channels (Lohman et al., 1997; Wei et al., 1998. Lucas et al., 2000).

\subsection{Somatostatin - NO interactions}

In this section, evidence will be presented that corroborate the role of NO/cGMP in mediating SRIF's actions. Emphasis will be given to SRIF's functions in retinal circuitry and in the regulation of GH secretion.

\subsubsection{Retinal Physiology}

The retina is part of the vertebrate central nervous system (CNS). Due to the simplicity of its anatomical organization, it has been used by many investigators as a model for the study of the neural mechanisms and neurotransmitter interactions in brain (Dowling, 1987). SRIF is present in the retina of many species where it is found in amacrine, ganglion, and interplexiform cells and believed to function as a neurotransmitter, neuromodulator or trophic factor (for a review see Thermos, 2003). The actions of SRIF in the retina are mediated by specific receptors as substantiated by pharmacological (Liapakis and Thermos, 1992, Liapakis et al., 1993; Vasilaki et al., 2003) and reverse transcriptase-polymerase chain reaction studies (Mori et al., 1997). Recent immunohistochemical studies have permitted the mapping of the ssts

present in retinal circuitry (Thermos, 2003). The function of these receptors is still 
under investigation, yet release studies in rat retinal explants supported the role of $\mathrm{sst}_{1}$ as an autoreceptor (Mastrodimou and Thermos, 2004, Thermos et al., 2006), in agreement with data from sst $_{1} \mathrm{KO}$ mice (Dal Monte et al., 2003a). In addition, sst $_{1}$ and $\mathrm{sst}_{2}$ have been shown to modulate dopamine (Kouvidi et al., 2006) and glutamate release (Dal Monte et al., 2003b).

Nitric oxide is also found in the retina where it functions as a neuromodulator. Initially, NADPH-diaphorase was found to be localized in a subpopulation of amacrine cells in rabbit retina (Sagar, 1990). Also in the rabbit, NADPH-diaphorase staining was found in addition to amacrine cells, in the inner segments of photoreceptors, horizontal cell, rod bipolar cells and ganglion cells (Osborne et al., 1993, Vasilaki et al., 2001). The presence of NOS was also examined in retinas of other species. In the turtle retina, nNOS-like immunoreactivity (LI) was prominent in amacrine cells but also visible in bipolar and horizontal cell processes at photoreceptor synapses. Similarly in rat, nNOS-LI was confined to well labelled $\underline{\text { amacrine cells and rod bipolar and B-type horizontal cell axon terminals at rod ribbon }}$ synapses (Haverkamp and Eldred, 1998). NADPH-diaphorase staining was also compared to the distribution of nNOS immunoreactivity (Perez et al., 1995, Roufail et al., 1995) to ensure equivalence between the two markers.

NOS immunoreactivity was seen in a small population of cells in the proximal inner nuclear layer of rat and rabbit retina. In the study by Perez et al. (1995), most of $\underline{\text { the labelled cells were amacrine cells with processes in the inner plexiform layer. A }}$ few labelled cells were also seen in the ganglion cell layer, suggested to be displaced $\underline{\text { amacrine cells. }} \underline{\text { In rat and rabbit, NADPH-diaphorase staining was observed in both }}$ species in photoreceptor inner segments, in cells with the position of horizontal cells, in a subset of amacrine and displaced amacrine cells, and in large cell bodies in the 
ganglion cell layer. However, colocalisation with NOS immunoreactivity was only observed among amacrine cells, but not all NADPH-diaphorase-reactive amacrine $\underline{\text { cells were found to be NOS immunoreactive (Perez et al., 1995). In studies performed }}$ in human and rat retinal flat mounts (Mitrofanis 1989, Mitrofanis and Provis, 1990), NADPH-diaphorase staining and nNOS immunoreactivity were absolutely colocalized $(100 \%)$ in amacrine cells located in the INL and in photoreceptor outer segments (Roufail et al., 1995).

The above mentioned studies support that nNOS is widely spread in the retina, having been localized in all retinal neurons. However, it is present predominantly in amacrine cells. SRIF is also primarily located in amacrine cells. Yet, colocalization of SRIF and NOS in amacrine cells has not been reported (Koistinaho and Sagar, 1995) as was the case in brain (Vincent and Johansson, 1983, Dawson et al., 1991, $\underline{\text { Kubota et al., 1994, Higo et al., 2007). }}$ To date, there are no data to suggest that the specific population of amacrine cells, which express the highest levels of NOS in the $\underline{\text { retina, coexpress SRIF. In addition, no reports are available to suggest colocalization }}$ $\underline{\text { of somatostatin receptors with NADPH-diaphorase or nNOS in amacrine cells, as was }}$ $\underline{\text { reported for the } \mathrm{sst}_{1}} \underline{\text { in SRIF- and } \mathrm{sst}_{1}} \underline{\text { and }}_{\mathrm{sst}_{2}} \underline{\mathrm{receptors}}$ in TH-containing amacrine cells (Helboe and Moller, 1999, Cristiani et al., 2000, Fontanesi et al., 2000).

However, colocalization of NADPH-diaphorase with somatostatin receptors in other retinal cells and the retinal pigment epithelium (RPE) has been reported. As shown in Figure 1, NADPH-diaphorase is colocalized with the $\mathrm{sst}_{1}$ receptor mainly in the RPE (rat) and blood vessels of the inner retina, with the $\mathrm{sst}_{2 \mathrm{~A}}$ on rod bipolar cells, with $\mathrm{sst}_{2 \mathrm{~B}}$ receptors in the RPE (human cultured cells) and photoreceptors, with the sst $_{4}$ in ganglion cell bodies and processes and with sst ${ }_{5}$ in human RPE cells (Vasilaki et al., 2001, 2002, 2004). These results supported for the first time a possible role of 
SRIF in the regulation of nitric oxide in the retina. However, in the mouse retina no colocalization was observed suggesting that in this species SRIF is not an important modulator of NO (Mastrodimou et al., 2006a).

In the literature, there are few studies measuring NO levels in the retina. Neal et al. (1998) demonstrated that NO was selectively released from retinal amacrine and bipolar cells in the rabbit retina, depending on the light stimulus employed. We conducted ex vivo experiments in retinal explants (RPE excluded), in order to investigate directly SRIF's regulation of NO production. The levels of NO in rat retinal explants were assessed by the production of its stable metabolites $\mathrm{NO}_{2}^{-}$and $\mathrm{NO}_{3}^{-}\left(\mathrm{NO}_{\mathrm{x}}{ }^{-}\right)$(Grisham et al.,1996). SRIF increased $\mathrm{NO}_{\mathrm{x}}^{-}$basal levels in a concentration dependent manner. This action of SRIF was mimicked only by $\mathrm{sst}_{2}$ receptor activation. The sst $_{2}$ specific agonist (L-779,976; Rohrer et al., 1998) was able to increase $\mathrm{NO}_{\mathrm{x}}{ }^{-}$levels (Figure 2), while the $\mathrm{sst}_{2}$ antagonist CYN-154806 (Bass et al., 1996; Feniuk et al., 2000) blocked the L-779,976 effect in retinal explants, supporting the pharmacological relevance of the sst $_{2}$ effect (Vasilaki et al., 2002).

The above studies were extended to the RPE, a monolayer of cells that is crucial for the integrity of the retina. Klisovic et al. (2001) detected the $\mathrm{sst}_{1}$ and $\mathrm{sst}_{2}$ genes and immunoreactivity in cultured RPE cells. The presence of SRIF and its receptor subtypes, $\mathrm{sst}_{2 \mathrm{~B}}$ and $\mathrm{sst}_{5}$, and NADPH-diaphorase were detected in human RPE cells (Vasilaki et al., 2004, Figure 1). As in retinal explants, SRIF increased the levels of $\mathrm{NO}_{\mathrm{x}}{ }^{-}$in a concentration-dependent manner via $\mathrm{sst}_{2}$ receptor activation (Vasilaki et al., 2004).

These results were unexpected due to the well known inhibitory nature of SRIF. The mechanism via which SRIF mediates its stimulatory effects on NO release in the retina and the RPE has not been elucidated. A calcium dependent mechanism known 
to be important in the synthesis of NO does not seem plausible, since SRIF is known to have an inhibitory role on intracellular calcium levels (Tallent et al., 1996, Cervia et al., 2003, Olias et al., 2004). However, a mechanism involving an SH2 domaincontaining protein tyrosine phosphatase (SHP-1) may be involved, since SHP-1 was shown to be present in retinal extracts (Figure 4A, Mastrodimou et al., 2006b).

SHP-1 is a negative regulator of growth and cytokine receptor signalling. In CHO cells coexpressing the sst $_{2}$ receptor and SHP-1, SRIF inhibited cell proliferation suggesting that SHP-1 may be an initial key transducer in the $\mathrm{sst}_{2}$ mediated antiproliferative actions (Lopez et al., 1997). In subsequent studies from the same group, nNOS was identified as a novel critical partner for sst $_{2}$ mediated cell arrest (Lopez et al., 2001). The investigators showed that sst $_{2}$ activation leads to the activation of SHP-1 which couples to nNOS and leads to its dephosphorylation. This process activates nNOS and increases NO synthesis and subsequent cGMP production believed to be instrumental in cell arrest.

NO is believed to play a variety of roles in ocular physiology. These include the maintenance of tight junction integrity (Zech et al., 1998), the development of immune and inflammatory responses and blood flow (Dezsi et al., 1997; Holtkamp et al., 2001). Our data suggest that SRIF may influence the above functions by its regulation of $\mathrm{NO}$ production, and the use of $\mathrm{NO}$ as a signalling molecule. The role of NO as a neuronal messenger and neuromodulator in retina is well established (Goldstein et al., 1996). As in other systems, it activates a soluble GC (Koch et al., 1994; Ding and Weinberg, 2007) leading to an increase in cGMP production. cGMP is an important regulator of retinal physiology, since it influences a series of biochemical substrates including ion channels (Meriney et al., 1994). It modulates gap 
junctions between horizontal cells (DeVries and Schwartz, 1989) and between amacrine and rod bipolar cells (Mills and Masey, 1995).

In a recent study, we showed that SRIF increased cGMP levels in retinal explants in a concentration dependent manner via a $\mathrm{SRIF} / \mathrm{sst}_{2} / \mathrm{NO}$ mechanism involving neuronal NOS (Figures 3, 4, Mastrodimou et al., 2006b). In addition, phosphotyrosine phosphatase SHP-1 (Lopez et al., 1997, 2001) was found to be present in the retina, and its inhibition by vanadate reversed SRIF's actions (Figure 4). Vanadate is not a selective inhibitor of SHP-1. While the data suggest a SRIF/SHP-1/NO/cGMP signalling pathway for SRIF's actions in the retina, the importance of other phosphotyrosine phosphatases cannot be excluded.

More recent studies support that NO and cGMP also modulate SRIF levels in the retina. Therefore, a reciprocal feedback regulation may exist to provide the finetuning of retinal circuitry (Kiagiadaki et al., 2008).

\subsubsection{GH Regulation}

SRIF was initially characterized as the substance found in hypothalamic extracts and inhibited growth hormone (GH, somatotropin) release from the pituitary (Krulich et al., 1968, Brazeau et al., 1973). In collaboration with the stimulatory GHreleasing hormone (GHRH), SRIF is responsible for the regulation of GH secretion from the pituitary gland (Tannenbaum and Epelbaum, 2000, Olias et al., 2004).

mRNAs of all somatostatin receptor subtypes (ssts) were shown, in earlier studies, to be expressed in the pituitary. However, the concentration of each receptor subtype present and its significance in regulating GH release was not absolutely clarified (Bruno et al., 1993, Day et al., 1995, O’Carroll and Krempels,1995). Subsequent immunocytochemistry studies confirmed the mRNA data by showing the 
colocalization of sst $_{1}$-sst 5 with GH in the normal rat pituitary somatotrophs (Kumar et al., 1997). This last study provided significant data to suggest that the sst subtype $^{2}$ was the predominant one in the pituitary, since it was localized in all somatotrophs. The other subtypes were expressed in the following order, $\mathrm{sst}_{2}>\mathrm{sst}_{4}>\mathrm{sst}_{3}>\mathrm{sst}_{1}$.

However, functional studies supported the importance of both the $\mathrm{sst}_{2}$ and $\mathrm{sst}_{5}$ subtypes in the regulation of GH release. Activation of $\mathrm{sst}_{2}$ and $\mathrm{sst}_{5}$ receptors led to the inhibition of GH release in human fetal pituitary cultures (Shimon et al., 1997), rat pituitary cells (Rohrer et al., 1998), and inhibited the GHRH-stimulated GH release in rat anterior pituitary cells (Parmar et al., 1999).

In later studies, the involvement and importance of the sst $_{1}$ subtype in the control of GH secretion became evident. Primary cell cultures from pituitaries of wild-type sst $_{1}$ mice exposed to the sst $_{1}$ selective somatostatin analog $\mathrm{CH}-275$ showed reduction of basal levels of $\mathrm{GH}$ secretion, whereas somatotrophs isolated from $\mathrm{sst}_{1}$ null mutant mice did not respond to the agonist-mediated effect (Kreinenkamp et al., 1999). Other studies showed that GHRH regulated, both in vivo and in vitro, $\mathbf{s s t}_{1}$, $\mathrm{sst}_{2}$, and $\mathrm{sst}_{5}$ mRNA levels in rat pituitary (Park et al., 2000). In human pituitary adenomas $\mathrm{sst}_{1}$ mRNA levels correlated with the degree of inhibition of GH secretion. (Zatelli et al., 2003). Studies focusing on the elucidation of the signalling pathways involved in the SRIF inhibition of GH release supported the involvement of cAMPand $\mathrm{Ca}++$-dependent pathways (Epelbaum et al., 1987, Goodyer et al., 1993). More recent data support that the activation of $\mathrm{sst}_{1}, \mathrm{sst}_{2}$, and $\mathrm{sst}_{5}$ inhibits $\mathrm{GH}$ release in $\mathrm{GC}$ rat tumour somatotrophs via cAMP- and $\mathrm{Ca}^{++}$- dependent and independent pathways (Cervia et al., 2002, 2003).

During the last decade, very interesting findings were reported in pig somatotrophs (Castaño et al., 2005). Somatostatin was found to exert a dual role in 
GH release depending on its concentrations and the density of the somatotrophs (Ramirez et al., 1997, 1998). High concentrations of SRIF $\left(>10^{-8} \mathrm{M}\right)$ inhibit the GHRH-induced, but not the spontaneous GH secretion, while low concentrations $\left(<10^{-10} \mathrm{M}\right)$ stimulate $\mathrm{GH}$ secretion without altering the effect of GHRH (Castaño et al., 1996; Ramirez et al., 1997). The stimulatory effects of SRIF are coupled to a cAMP dependent pathway but the role of intracellular $\mathrm{Ca}^{++}$in SRIF's actions was not apparent (Ramirez et al., 2002). In further pursuit of the intracellular mechanisms leading to this dual effect, Luque et al. (2005) studied the involvement of the NO/cGMP signalling pathway in SRIF's actions in the pig somatotroph, since previous studies had supported a functional role of NO in GH release (Pinilla et al., 1999, Bocca et al., 2000). NO generated cGMP was shown to be a necessary signal transduction component of GnRH-induced GH secretion (Uretsky et al., 2003). Luque et al. (2005) reported that NOS/NO plays a critical role in the stimulatory actions of low concentrations of SRIF on pig GH release, but without the involvement of cGMP. In another paradigm, SRIF inhibited the NO-mediated stimulation of GH release in goldfish pituitary somatotrophs (Yunker et al., 2003).

The above mentioned studies support a species-specific difference in SRIF's regulation of GH release. Whether a species - specific mechanism is responsible for the involvement of NO in SRIF's actions in the somatotroph remains to be addressed. However, SRIF has been shown to have a dual effect on the release of NO. In different paradigms it has been shown to increase and inhibit NO levels via the involvement of different receptor subtypes and intracellular pathways. As mentioned in the previous section, SRIF increases NO levels in the retina by activating the $\mathrm{sst}_{2}$ receptor, yet the mechanism involved has not been elucidated (Vasilaki et al., 2002). In another paradigm, sst $_{2}$ activation led to the increase in NO levels via a mechanism 
involving SHP-1. SHP-1 was shown to be essential for the SRIF-induced activation of nNOS both in vitro and in vivo and in the subsequent increase in cGMP levels that led to the inhibition of cell proliferation (Lopez et al., 2001). This work provided the

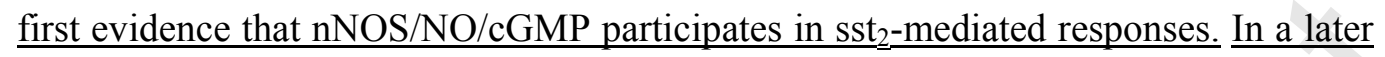
$\underline{\text { work, the same group demonstrated that somatostatin receptor subtypes can act }}$ antagonistically in regulating nNOS activity. It was shown that activation of the sst ${ }_{5}$ subtype induced a rapid inhibition of nNOS and the subsequent involvement of NO in the stimulation of cell proliferation (Cordelier et al., 2006 ).

$\underline{\text { SRIF-induced negative regulation of NO was also shown to be implicated in the }}$ $\underline{\text { inhibition of tumor angiogenesis and growth via the } \text { sst }_{3} \text {-mediated negative regulation }}$ of endothelial NOS (Florio et al., 2003). In a subsequent study, the sst inhibitory effects on NO production induced by different agents were studied and the receptor subtypes and the intracellular pathways involved were identified (Arena et al., 2005). Thus, somatostatin inhibited NO production that was stimulated by bFGF-dependent $\underline{\text { ceramide production (via sst }} \underline{1}_{1} \underline{s t}_{2}, \mathrm{sst}_{3}$ ), by CCK (via sst $\underline{2}_{2}, \mathrm{sst}_{3}$ ), but not by insulin. $\underline{\text { In CHO-sst }} \underline{2}_{2}$ and CHO- sst $_{3} \underline{\text { cells, somatostatin significantly reduced the intracellular }}$ $\underline{\mathrm{Ca}^{++}}$levels induced by $\mathrm{CCK}$, thus leading to the attenuation of $\mathrm{NO}$ production.

The data presented so far are derived from a relative small number of studies, yet identify $\mathrm{NO}$ as a signalling molecule mediating the functions of somatostatin. In some of the cited studies the role of NO/cGMP is evident, while in others either not studied or not applicable ( Lopez et al., 2001, Florio et al., 2003, Cordelier et al., 2006, Mastrodimou et al., 2006b). cGMP was not involved in the NO-dependent $\underline{\text { stimulatory actions of low concentrations of SRIF on pig GH release (Luque et al., }}$ 2005). While it is well accepted that NO-mediated actions are due to its activation of soluble guanylyl cyclase and the subsequent increases in cGMP levels, cGMP- 
independent mechanisms have also been attributed to NO functions. Interaction of NO-derived metabolites with thiols produces S-nitrosothiols. This process of Snitrosylation leads to posttranslational protein modification that occurs independently of $\mathrm{sGC} / \mathrm{cGMP}$ and represents another signal transduction pathway that influences mammalian physiology (Foster et al., 2003, Bryan et al., 2004).

Further studies are essential in order to investigate the stimulatory or inhibitory regulation of NOS activity by the different ssts in different tissues and cellular functions, as well as the down stream events that are activated by SRIF/sst/ NO signalling pathways. The data obtained will aid the elucidation of the mechanisms involved in the plethora of SRIF's functions via the activation of specific receptor subtypes and signalling molecules.

\section{NO/cGMP as mediators of the neuroprotective effects of somatostatin}

In recent years, research has been directed towards the search of agents that ameliorate neuronal damage and protect the CNS, including the retina, from excitotoxicity and ischemia. Retinal ischemia leads to vision impairment and blindness. Ischemia induces the activation of voltage-gated calcium channels and ionotropic glutamate receptors, which result in the rise in intracellular calcium levels and the subsequent activation of NO formation. These events are believed to be important in cell death. In addition, ischemia is believed to be the underlying cause of neovascularization, a process that leads to retinal diseases such as proliferative retinopathies, retinopathy of prematurity, and diabetic retinopathy (Osborne et al., 2004).

A number of in vivo and in vitro models of retinal ischemia and neovascularization have been developed in order to study the biochemical players 
involved in these processes, and to investigate possible neuroprotective agents to be used therapeutically in retinal diseases.

SRIF and its $\mathrm{sst}_{2}$ specific analogs were shown to inhibit retinal neovascularization in a mouse model of oxygen-induced retinopathy (Smith et al.,1997; Higgins et al., 2002), and to reduce ischaemia-reperfusion injury in the retina (Celiker et al., 2002). We employed a chemical model of ischemia ( $\mathrm{NaCN} /$ iodoacetic acid) which involves the blockade of oxidative phosphorylation and glycolysis, and is believed to be useful in the understanding of the early events underlying the pathophysiology of ischemia. In this model, somatostatin analogs selective for the $\mathrm{sst}_{2}$ subtype protected the retina from the ischemic insult and were successful in reversing retinal cell death (Mastrodimou et al., 2005). Recent data have shown that the increased presence of $\mathrm{sst}_{2}$ receptors, in retinas of mice not expressing the $\mathrm{sst}_{1}$ receptor subtype, protected the retina from ischemia (hypoxia and iodoacetic acid) (Catalani et al., 2007). In the same animals, the overexpression of the sst $_{2}$ receptors was shown to afford antiangiogenic effects in a hypoxia-induced model of neovascularization (Dal Monte et al., 2007).

The mechanisms via which somatostatinergic ligands act as neuroprotectants are still under investigation. The ability of somatostatin and analogs to inhibit the release of growth factors such as GH and IGF have implicated SRIF as an antiangiogenic agent (Smith et al.,1997; Higgins et al., 2002). SRIF inhibits IGF-1 mediated induction of VEGF in hRPE cells, (Sall et al., 2004) and octreotide (sst $2 / 5$ agonist) has been shown to prevent growth factor - induced proliferation of bovine retinal endothelial cells under hypoxia (Baldsiak-Figiel et al., 2004).

Somatostatin is also known to inhibit voltage-gated calcium channels (Tallent et al., 1996), and neuronal calcium currents, the latter via a mechanism involving a 
cGMP-dependent protein kinase (Meriney et al.,1994). cGMP was shown to be important in somatostatin's protective actions against NMDA induced neuronal death in cortical cultures (Forloni et al., 1997).

The study by Mastrodimou et al. (2005) suggested that rod bipolar and tyrosinehydroxylase sst $_{2}$ containing neurons were protected from the ischemic insult, possibly due to the $\mathrm{sst}_{2}$ involvement in the attenuation of calcium levels. However, the neuroprotection afforded to cholinergic and nNOS containing neurons, that lack $\mathrm{sst}_{2}$ receptors, could not be explained.

As presented in previous sections, studies in our laboratory have shown that somatostatin increases NO (Vasilaki et al., 2002) and cGMP levels in rat retinal explants (Mastrodimou et al., 2006b) via a sst $_{2}$ mechanism. Therefore, one can conjecture that NO may trigger the synthesis of cGMP in neighboring cells, not containing somatostatin receptors, and provide neuroprotection.

NO is considered a major player in the ischemia induced cell death, and has also been shown to promote ocular neovascularization. However, there are studies to suggest that NO also antagonizes ocular neovascularization. In a study by Ando et al. (1992), pharmacological inhibition of NOS did not reduce ischemia-induced retinal neovascularization. Also, the employment of mice lacking individual or all three NOS isoforms suggested that iNOS and /or nNOS, in cells adjacent to endothelial cells in the presence of retinal ischemia have an antiangiogenic effect.

In a recent study, we investigated whether NO and / or cGMP could protect the retina from chemical ischemia insults and whether this may represent a putative mechanism for somatostatin's neuroprotective effects in the retina. The slow NO donor NONOate, the NO/peroxynitrite donor SIN-1 and 8-Br-cGMP protected the retina in a concentration-dependent manner. Furthermore, the NOS inhibitor NMMA 
and two sGC inhibitors tested, ODQ and NS 2028, reversed the protective effect of the $\mathrm{sst}_{2 / 5}$ analog lanreotide, thus implicating $\mathrm{NO} / \mathrm{sGC}$ and cGMP in the neuroprotection. The selective sst $_{5}$ agonist (L-817-818) had no effect on NO release in retinal explants, thus we can suggest that lanreotide's neuroprotective effects are $\mathrm{sst}_{2}$ mediated. Retinal viability in all paradigms was determined by choline acetyl transferase immunoreactivity and TUNEL staining (Mastrodimou et al, 2008). The major finding of this study was that the $\mathrm{NO} / \mathrm{sGC} / \mathrm{cGMP}$ pathway is involved in the neuroprotection bestowed on the retina by the $\mathrm{sst}_{2}$ analog.

\section{Conclusions}

The aim of this review was to summarize the knowledge acquired to date on the role of NO/cGMP in somatostatin's functions. It is becoming evident that SRIF differentially influences NOS activities, leading to an increase or decrease of NO production, with a subsequent respective effect on cGMP levels. In the retina, both SRIF and NO are neuromodulators of retinal circuitry. SRIF increases NO and cGMP levels thus influencing retinal physiology. In addition, in a chemical model of retinal ischemia NO/cGMP mediated SRIF's neuroprotective effects on retinal neurons. In porcine somatotrophs, NO mediated independently of cGMP the SRIF dependent GH stimulation. A more detailed investigation is essential in order to pinpoint the exact players involved in each step of the cascade pertaining to the involvement of NO/cGMP in SRIF's physiological and protective actions (NOS, NO, sGC, cGMP, cGMP-dependent kinases). This would delineate further the SRIF-NO relationship and its importance in normal and diseased conditions and possibly therapeutics. 


\section{Acknowledgements}

The work presented in this review was co-funded by the European Social Fund and National Resources [Program Pythagoras]. The author thanks Dr Anna Vasilaki, Ms Niki Mastrodimou and Ms Foteini Kiagiadaki for their scientific contributions.

\section{References}

Akopian, A., Johnson, J., Gabriel, R., Brecha, N., Witkovsky, P., 2000. Somatostatin modulates voltage-gated $\mathrm{K}^{+}$and $\mathrm{Ca}^{++}$currents in rod and cone photoreceptors of the salamander retina. J. Neurosci. 20, 929-936.

Alderton, WK., Cooper, C E ., Knowles, RG., 2001. Nitric oxide synthases: structure, function and inhibition. Biochem. J. 357, 593-615.

Allen, J.P., Hathway, G.J., Clarke, N.J., Jowett, M.I., Topps, S., Kendrick, K.M., Humphrey, P.P., Wilkinson, L.S., Emson, P., 2003. Somatostatin receptor 2 knockout/lacZ knockin mice show impaired motor coordination and reveal sites of somatostatin action within the striatum. Eur. J. Neurosci. 17, 1881-1895.

Ando, A., Yang, A., Nambu, H., Campochiaro, P.A., 1992. Blockade of nitric-oxide synthase reduces choroidal neovascularization. Mol. Pharmacol. 62, 539-544.

Arena, S., Pattarozzi, A., Corsaro, A., Schettini, G., Florio, T., 2005. Somatostatin receptor subtype-dependent regulation of nitric oxide release: involvement of different intracellular pathways. Mol. Endocrinol. 19, 255-267.

Baldsiak-Figiel, A., Lang, G.K., Kampmeier, J., Lang, G.E., 2004. Octreotide prevents growth factor-induced proliferation of bovine retinal endothelial cells under hypoxia. J. Endocrinol. 180, 417-424. 
Bass, R.T., Buckwalter, B.L., Patel, B.P., Pausch, M.H., Price, L.A., Strand, J., Hadcok, J.R., 1996. Identification and characterization of novel somatostatin antagonists. Mol. Pharmacol. 50, 709-715 [erratum in Mol. Pharmacol. 1997, 51:170].

Bocca, L., Valenti, S., Cuttica, C.M., Spaziante, R., Giordano, G., Giusti, M., 2000. Nitric oxide biphasically modulates GH secretion in cultured cells of GH-secreting human pituitary adenomas. Minerva Endocrinol. 25, 55-59.

Brazeau, P., Vale, W., Burgus, R., Ling, N., Butcher, M., Rivier, J., Guillemin, R., 1973. Hypothalamic polypeptide that inhibits the secretion of immunoreactive pituitary growth hormone. Science $179,77-79$.

Bredt, D.S., Snyder, S.H., 1992. Nitric oxide, a novel neuronal messenger. Neuron. 8, $3-11$.

Bruno, J.F-., Xu, Y., Song, J., Berelowitz, M., 1993. Tissue distribution of somatostatin receptor subtype messenger ribonucleic acid in the rat. Endocrinology $133,2561-2567$.

Bryan, N.S., Rassaf, T., Maloney, R.E., Rodriguez, C.M., Saijo, F., Rodriguez, J.R., Feelisch, M., 2004. Cellular targets and mechanisms of nitros(yl)ation : An insight into their nature and kinetics in vivo. Proc. Natl. Acad. Sci. (USA) 101, 4308-4313. Castaño, J.P., Torronteras, R., Ramirez, J.L, Gribouval, A., Sanchez-Hormigo, A., Ruiz-Navarro, A., Gracia-Navarro, F., 1996. Somatostatin increases growth hormone (GH) secretion in a subpopulation of porcine somatotrophss: evidence for functional and morphological heterogeneity among porcine GH-producing cells. Endocrinology $137,129-136$.

Castaño, J.P., Delgado-Niebla, E., Durán-Prado, M., Luque, R.M., Sánchez-Hormigo, A., Gracia-Navarro, F., García-Navarro, S., Kineman, R.D., Malagón, M.M., 2005. 
New insights in the mechanism by which SRIF influences GH secretion. J. Endocrinol. Invest. 28, 10-13.

Catalani, E., Cervia, D., Martini, D., Bagnoli, P., Simonetti, E., Timperio, A.M., Casini, G., 2007. Changes in neuronal response to ischemia in retinas with genetic alterations of somatostatin receptor expression. Eur. J. Neurosci. 25, 1447-1459.

Celiker, U., Ilhan, N., Ozercan, I., Demir, T., Celiker, H., 2002.Octreotide reduces ischaemia-reperfusion injury in the retina. Acta Ophthalmol. Scand. 80, 395-400.

Cervia, D., Fiorini, S., Pavan, B., Biondi, C., Bagnoli, P., 2002. Somatostatin (SRIF) modulates distinct signaling pathways in rat pituitary tumor cells; negative coupling of SRIF receptor subtypes 1 and 2 to arachidonic acid release. Naunyn Schmied.Arch. Pharmacol. 365, 200-209.

Cervia, D., Zizzari, P., Pavan, B., Schuepbach, E., Langenegger, D., Hoyer, D., Biondi, C., Epelbaum, J., Bagnoli, P., 2003. Biological activity of somatostatin receptors in GC rat tumour somatotrophs: evidence with sst1-sst5 receptor-selective nonpeptidyl agonists. Neuropharmacology. 44, 672-685.

Cordelier, P., Estève, J.P., Najib, S., Moroder, L., Vaysse, N., Pradayrol, L., Susini, C., Buscail, L., 2006. Regulation of neuronal nitric-oxide synthase activity by somatostatin analogs following SST5 somatostatin receptor activation. J. Biol. Chem. 281, 19156-19171 .

Cristiani, R., Fontanesi, G., Casini, G., Petrucci, C., Viollet, C., Bagnoli, P., 2000. Expression of somatostatin subtype 1 receptor in the rabbit retina. Invest. Ophthalmol. Vis. Sci. 41, 3191-3199.

Csaba, Z., Dournaud, P., 2001. Cellular biology of somatostatin receptors. Neuropeptides. 35, 1-23. 
Dal Monte, M., Petrucci, C., Vasilaki, A., Cervia, D., Grouselle, D., Epelbaum, J., Kreienkamp, H.J., Richter, D., Hoyer, D., Bagnoli, P.. 2003a. Genetic deletion of somatostatin receptor 1 alters somatostatinergic transmission in the mouse retina. Neuropharmacology. 45, 1080-1092.

Dal Monte, M., Petrucci, C., Cozzi, A., Allen, J.P,, Bagnoli, P., 2003b. Somatostatin inhibits potassium-evoked glutamate release by activation of the $\operatorname{sst}(2)$ somatostatin receptor in the mouse retina. Naunyn Schmied. Arch. Pharmacol. 367, 188-192.

Dal Monte, M., Cammalleri, M., Martini, D., Casini, G., Bagnoli, P., 2007. Antiangiogenic role of somatostatin receptor 2 in a model of hypoxia-induced neovascularization in the retina: results from transgenic mice. Invest. Ophthalmol. Vis. Sci. $48,3480-3489$.

Day, R., Dong, W., Panetta, R., Kraicer J., Greenwood, M.T., Patel, Y.C., 1995. Expression of mRNA for somatostatin receptor (sstr) types 2 and 5 in individual pituitary cells. A double labelling in situ hybridizatin analysis. Endocrinology. 136, $5232-5235$

Dawson, T.M., Bredt, D.S., Fotuhi, M., Hwang, P.M., Snyder, S.H., 1991. Nitric oxide synthase and neuronal NADPH diaphorase are identical in brain and peripheral tissues. Proc. Nat. Acad. Sci. (U SA) 88, 7797-7801.

DeVries, S.H., Schwartz, E.A., 1989. Modulation of an electrical synapse between solitary pairs of catfish horizontal cells by dopamine and second messengers. J. Physiol. 414, 351-375.

Dézsi, L., Dörnyei, G., Szentiványi, M., Tulassay, T., Monos, E., 1997. Somatostatin induces vasodilatation in the cat mesenteric artery via endothelium-derived nitric oxide and prostaglandins. Pflugers Arch. 433, 536-538. 
Ding, J.D., Weinberg, R.J., 2007. Distribution of soluble guanylyl cyclase in rat retina. Comp. Neurol. 500, 734-745 [Corrected and republished in: J. Comp. Neurol.502, 734-745].

Dowling, J.E., 1987. The Retina , Harvard University Press.

Epelbaum, J., Enjalbert, A., Krantic, S., Musset, F., Bertrand, P., Rasolonjanahary, R., Shu, C., Kordon, C., 1987. Somatostatin receptors on pituitary somatotrophs, thyrotrophs, and lactotrophs: pharmacological evidence for loose coupling to adenylate cyclase. Endocrinology. 121, 2177-2185.

Feniuk, W., Jarvie, E., Luo, J., Humphrey, P.P.A., 2000. Selective somatostatin sst2 receptor blockade with the novel cyclic octapeptide, CYN-154806. Neuropharmacology. 39, 1443-1450.

Florio, T., Morini, M., Villa, V., Arena, S., Corsaro, A., Thellung, S., Culler, M.D., Pfeffer, U., Noonan, D.M., Schettini, G., Albini, A., 2003. Somatostatin inhibits tumor angiogenesis and growth via somatostatin receptor-3-mediated regulation of endothelial nitric oxide synthase and mitogen-activated protein kinase activities. Endocrinology. 144, 1574-1584.

Fontanesi, G., Gargini, C., Bagnoli, P., 2000. Postnatal development of somatostatin $\underline{2 \mathrm{~A} \text { (sst2A) receptors expression in the rabbit retina. Brain Res. Dev. Brain Res.123, }}$ $\underline{67-80}$

Forloni, G., Lucca, E., Angeretti, N., Chiessa, R., Vezzani, A., 1997. Neuroprotective effect of somatostatin on nonapoptotic NMDA-induced neuronal death: role of cyclic GMP. J. Neurochem. 68, 319-27.

Foster, M.W., McMahon, T.J., Stamler, J.S., 2003. S-nitrosylation in health and disease. Trends Mol. Med. 9, 160-168. 
Goldstein, I.M., Ostwald, P., Roth, S., 1996. Nitric oxide: a review of its role in retinal function and disease. Vision Res. 36, 2979-2994.

Goodyer, C.G., Branchaud, C.L., Lefebvre, Y., 1993. In vitro modulation of growth hormone (GH) secretion from early to midgestation human fetal pituitaries by GHreleasing factor and somatostatin: role of Gs-adenylate cyclase-Gi complex and $\mathrm{Ca} 2+$ channels. J. Clin. Endocrinol. Metab. 76, 1265-1270.

Grisham, M.B., Johnson, G.G., Lancaster, J.R.J., 1996. Quantification of nitrate and nitrite in extracellular fluids. Methods Enzymol. 268, 237-246.

Haverkamp, S., Eldred ,W.D., 1988. Localization of nNOS in photoreceptor, bipolar and horizontal cells in turtle and rat retinas. Neuroreport 9, 2231-2235.

Helboe, L., Moller, M., 1999. Immunohistochemical localization of somatostatin receptor subtypes sst1 and sst2 in the rat retina. Invest. Ophthalmol. Vis. Sci. 40, 2376-2382.

Higgins, R.D., Yan, Y., Schrier, B.K., 2002. Somatostatin analogs inhibit neonatal retinal neovascualrisation. Exp. Eye Res. 74, 553-559.

Higo, S., Udaka, N., Tamamaki, N., 2007. Long-range GABAergic projection neurons in the cat neocortex. J. Comp. Neurol. 503, 421-431.

Holtkamp, G.M., Kijlstra, A., Peek, R., de Vos, A.F., 2001. Retinal pigment epithelium-immune system interactions: cytokine production and cytokine-induced changes. Prog. Retinal Eye Res. 20, 29-48.

Hoyer, D., Bell, G.I., Berelowitz, M., Epelbaum, J., Feniuk, W., Humprey P.P., O'Carroll, A.M., Patel, Y.C., Schonbrunn, A., Taylor, J.E., Reisine, T., 1995. Classification and nomenclature of somatostatin receptors. Trends Pharmacol. Sci. $16,86-88$ 
Hoyer, D., Nunn, C., Hannon, J., Schoeffter, P., Feuerbach, D., Schuepbach, E., Langenegger, D., Bouhelal, R., Hurth, K., Neumann, P., Troxler, T., Pfaeffli, P., 2004. SRA880, in vitro characterization of the first non-peptide somatostatin $\operatorname{sst}(1)$ receptor antagonist. Neurosci. Lett. 361, 132-135.

Kiagiadaki, F., Koulakis, E., Thermos, K., 2008. Dopamine (D1) receptor activation and nitrinergic agents influence somatostatin levels in rat retina. Exp. Eye Res. 86, $18-24$.

Klisovic, D.D., O’ Dorisio, M.S., Katz, S.E., Sall, J.W., Balster, D., O’ Dorisio, T.M., Craig, E., Lubow, M., 2001. Somatostatin receptor gene expression in human ocular tissues: RT-PCR and immunohistochemical study. Invest. Ophthalmol. Vis. Sci. 42, 2193-2201.

Koch, K.-W., Lambrecht, H.-G., Haberecht, M., Redburn, D., Schmidt, H. H.H.W., 1994. Functional coupling of $\mathrm{Ca}^{+2} /$ calmodulin-dependent nitric oxide synthase and a soluble guanylyl cyclase in vertebrate photoreceptor cells. EMBO J. 13, 3312-3320. Koesling, D., Russwurm, M., Mergia, E., Mullershausen, F., Friebe, A., 2004. Nitric oxide-sensitive guanyl cyclase: structure and regulation. Neurochem. Int. 45, 813819.

Koistinaho, J., Sagar S.M., 1995. Light-induced c-fos expression in amacrine cells in the rabbit retina. Mol. Brain Res. 29, 53-63.

Kouvidi, E., Papadopoulou-Daifoti, Z., Thermos, K., 2006. Somatostatin modulates dopamine release in rat retina. Neurosci. Lett. 391, 82-86. 
Kreienkamp, H.J., Akgun, E., Baumeister, H., Meyerhof, W., Richter, D., 1999. Somatostatin receptor subtype 1 modulates basal inhibition of growth hormone release in somatotrophs. FEBS Lett. 462, 464-466.

Krulich, L., Dhariwal, AP., McCann, S.M., 1968. Stimulatory and inhibitory effects of purified hypothalamic extracts on growth hormone release from rat pituitary in vitro. Endocrinology. 83, 783-790.

Kubota, Y., Hattori, R., Yui, Y., 1994. Three distinct subpopulations of GABAergic neurons in rat frontal agranular cortex. Brain Res. 649, 159-173.

Kumar, U., Laird, D., Srikant, C.B., Escher, E., Patel, Y.C., 1997. Expression of the five somatostatin receptor (SSTR1-5) subtypes in rat pituitary somatotrophes: quantitative analysis by double-layer immunofluorescence confocal microscopy. Endocrinology. 138, 4473-4476.

Liapakis, G.,Thermos, K., 1992. Characterization of $\left[{ }^{125} \mathrm{I}\right]$ Tyr ${ }^{11}$-Somatostatin binding sites in the rabbit retina. Neuropeptides. 21, 13-19.

Liapakis, G., Politou, E., Thermos, K., 1993. Solubilization of somatostatin receptors from rabbit retina. Biochem. Pharmacol. 45, 1821-1828.

Lohman, S.M., Vaandrager, A.B., Smolenski, A., Walter, U., DeJone, H.R., 1997. Distinct and specific functions of cGMP-dependent protein kinases. Trends Biochem. Sci. $22,307-312$

Lopez, F., Estève, J.P,, Buscail, L., Delesque, N., Saint-Laurent, N., Théveniau, M., Nahmias, C., Vaysse, N., Susini, C., 1997. The tyrosine phosphatase SHP-1 associates with the sst 2 somatostatin receptor and is an essential component of sst2-mediated inhibitory growth signaling. J. Biol .Chem. 272, 24448-24454.

Lopez, F., Ferjoux, G., Cordelier, P., Saint-Laurent, N., Esteve, J.P., Vaysee, N., Buscail, L., Susini, C., 2001. Neuronal nitric oxide synthase: a substrate for SHP-1 
inolved in sst2 somatostatin receptor growth inhibitory signaling. FASEB J. 15, 2300-2302.

Lucas, K.A., Pitari, G.M,, Kazerounian, S., Ruiz-Stewart, I., Park, J., Schulz, S., Chepenik, K.P., Waldman, S.A., 2000. Guanylyl cyclases and signaling by cyclic GMP. Pharmacol. Rev. 52, 375-414.

Luque, R.M., Rodríguez-Pacheco, F., Tena-Sempere, M., Gracia-Navarro, F., Malagón, M.M,, Castaño. J.P., 2005. Differential contribution of nitric oxide and cGMP to the stimulatory effects of growth hormone-releasing hormone and lowconcentration somatostatin on growth hormone release from somatotrophs. J. Neuroendocrinol. 17, 577- 582.

Mahy, N., Woolkalis, M., Thermos, K., Carlson, K., Manning, D., Reisine, T., 1988. Pertussis toxin modifies the somatostatin receptor in anterior pituitary tumor cells. J. Pharmacol. Exp. Ther. 246, 779-785.

Mastrodimou, N., Thermos, K., 2004. The somatostatin receptor (sst1) modulates the release of somatostatin in rat retina. Neurosci. Lett. 356, 13-16.

Mastrodimou, N., Lambrou, G.N., Thermos, K., 2005. Effect of somatostatin analogues on chemically induced ischaemia in the rat retina. Naunyn Schmiedebergs Arch.. Pharmacol. 371, 44-53.

Mastrodimou, N., Vasilaki, A., Papadioti ,A., Low, M.J., Hoyer, D., Thermos, K., 2006a. Somatostatin receptors in wildtype and somatostatin deficient mice and their involvement in nitric oxide physiology in the retina. Neuropeptides. 40, 365-373.

Mastrodimou, N., Kiagiadaki, F., Hodjarova, M., Karagianni, E., Thermos, K., $2006 \mathrm{~b}$. Somatostatin receptors (sst2) regulate cGMP production in rat retina. Regul. Pept. $133,41-46$. 
Mastrodimou,N., Kiagiadaki, F., Thermos, K., 2008. The role of nitric oxide and cGMP in somatostatin's protection of retinal ischemia. Invest. Ophthalmol. Vis. Sci. $49,342-349$.

Meriney, S.D., Gray, D.B., Pilar, G.R., 1994. Somatostatin-induced inhibition of neuronal $\mathrm{Ca}^{2+}$ current modulated by cGMP-dependent protein kinase. Nature 369 , 336-339.

Mills, S.L., Massey, S.C., 1995. Differential properties of two gap junctional pathways made by AII amacrine cells. Nature 377, 734-737.

Mitrofanis J., 1989. Development of NADPH-diaphorase cells in the rat's retina. Neurosci. Lett. 102, 165-172.

Mitrofanis, J., Provis, J.M., 1990. NADPH-diaphorase neurons of human retinae have a uniform topographic distribution. Vis. Neurosci. 4, 619-623.

Møller, L,N,, Stidsen, C.E,, Hartmann, B., Holst, J.J., 2003. Somatostatin receptors. Biochim. Biophys Acta. 1616, 1-84.

Mori, M., Ahara, M., Shimizu, T., 1997. Differential expression of somatostatin receptors in the rat eye: SSTR4 is intensely expressed in the iris/ ciliary body. Neurosci. Lett. 223, 185-188.

Nathan, C., Xie, Q.W., 1994. Nitric oxide synthases: roles, tolls, and controls. Cell 78, $915-918$.

Neal, M., Cunningham, J., Matthews, K., 1998. Selective release of nitric oxide from retinal amacrine and bipolar cells. Invest. Ophthalmol. Vis. Sci. 39, 850-853.

O’Carroll, A-M., Krempels, K., 1995. Widespread distributin of somatostatin receptor messenger ribonucleic acids in rat pituitary. Endocrinology. 136, 5224-5227.

Olias, G., Viollet, C., Kusserow, H., Epelbaum, J., Meyerhof, W., 2004. Regulation and function of somatostatin receptors. J. Neurochem. 89, 1057-1091. 
Osborne, N.N., Barnett, N.L., Herrera, A.J., 1993. NADPH diaphorase localization and nitric oxide synthetase activity in the retina and anterior uvea of the rabbit eye. Brain Res. 610, 194-198.

Osborne, N.N., Casson, R.J., Wood, J.P., Chidlow, G., Graham, M., Melena, J., 2004. Retinal ischemia: mechanisms of damage and potential therapeutic strategies. Prog. Retin. Eye Res. 23, 91-147.

Park, S., Kamegai, J., Johnson, T.A., Frohman, L.A., Kineman, R.D., 2000. Modulation of pituitary somatostatin receptor subtype (sst1-5) messenger ribonucleic acid levels by changes in the growth hormone axis. Endocrinology. 141, 3556-3563. Parmar, R.M., Chan, W.W., Dashkevicz, M., Hayes, E.C., Rohrer, S.P., Smith, R.G., Schaeffer, J.M., Blake, A.D., 1999. Nonpeptidyl somatostatin agonists demonstrate that sst2 and sst5 inhibit stimulated growth hormone secretion from rat anterior pituitary cells. Biochem. Biophys. Res. Commun. 263, 276-280.

Patel, Y.C., 1999. Somatostatin and its receptor family. Front Neuroendocrinol. 20, 157-198.

$\underline{\text { Perez, M.T., Larsson, B., Alm, P., Andersson, K.E., Ehinger, B., 1995. Localisation }}$ of neuronal nitric oxide synthase-immunoreactivity in rat and rabbit retinas. Exp. Brain. Res. 104, 201-217.

Pinilla, L., Tena-Sempere, M., Aguilar, E., 1999. Nitric oxide stimulates growth hormone secretion in vitro through a calcium- and cyclic guanosine monophosphateindependent mechanism. Horm Res. 51, 242-247.

Ramírez, J.L., Torronteras, R., Castaño, J.P., Sánchez-Hormigo, A., Garrido, J.C., García-Navarro, S., Gracia-Navarro, F., 1997. Somatostatin plays a dual, stimulatory/inhibitory role in the control of growth hormone secretion by two somatotrophs subpopulations from porcine pituitary. J. Neuroendocrinol. 9, 841-848. 
Ramírez, J.L., Castaño, J.P., Gracia-Navarro, F., 1998. Somatostatin at low doses stimulates growth hormone release from intact cultures of porcine pituitary cells. Horm. Metab. Res. 30, 175-177.

Ramírez, J.L., Gracia-Navarro, F., García-Navarro, S., Torronteras, R., Malagón, M.M., Castaño, J.P., 2002. Somatostatin stimulates GH secretion in two porcine somatotrope subpopulations through a cAMP-dependent pathway. Endocrinology. $143,889-897$.

Reisine, T., Bell, G.I., 1995. Molecular biology of somatostatin receptors. Endocrine Rev. 16, 427-442.

Reubi, J.C., Schaer, J.C., Wenger, S., Hoeger, C., Erchegyi, J., Waser, B., Rivier, J., 2000. SST3-selective potent peptidic somatostatin receptor antagonists. Proc. Natl. Acad. Sci. (USA) 97, 13973-13978.

Rohrer, S.P., Birzin, E.T., Mosley, R.T., Berk, S.C., Hutchins, S.M., Shen, D-M., Xiong, Y., Hayes, E.C., Parmar, R.M., Foor, F., Mitra, S.W., Degrado, S.J., Shu, M., Klopp, J.M., Cai, S-J., Blake, A., Chan, W.W.S., Pasternak, A., Yang, L., Patchett, A.A., Smith, R.G., Chapman, K.T., Schaeffer, J.M., 1998. Rapid identification of subtype-selective agonists of the somatostatin receptor through combinatorial chemistry. Science $282,737-740$.

Roufail, E., Stringer, M., Rees, S., 1995. Nitric oxide synthase immunoreactivity and NADPH diaphorase staining are co-localised in neurons closely associated with the vasculature in rat and human retina. Brain Res. 684, 36-46.

Sagar, S.M., 1990. NADPH-diaphorase reactive neurons of the rabbit retina: differential sensitivity to excitotoxins and unusual morphologic features. J. Comp. Neurol. 300, 309-319. 
Sall, J.W., Klisovic, D.D., O’Dorisio, M.S., Katz, S.E., 2004. Somatostatin inhibits IGF-1 mediated induction of VEGF in human retinal pigment epithelial cells. Exp. Eye Res. 79, 465-476.

Schulz, S., Handel, M., Schreff, M., Schmidt, H., Hollt, V., 2000. Localisation of five somatostatin receptors in the rat central nervous system using subtype-specific antibodies. J. Physiol. (Paris), 94, 259-264.

Shimon, I., Taylor, J.E., Dong, J.Z., Bitonte, R.A., Kim, S., Morgan, B., Coy, D.H., Culler, M.D., Melmed, S., 1997. Somatostatin receptor subtype specificity in human fetal pituitary cultures. Differential role of SSTR2 and SSTR5 for growth hormone, thyroid-stimulating hormone, and prolactin regulation. J. Clin. Invest. 99, 789-798.

Smith, L.E.H., Kopchick, J.J., Chen, W., Knapp, J., Kinose, F., Daley, D., Foley, E., Smith, R.G., Schaeffer, J.M., 1997. Essential role of growth hormone in ischemiainduced retinal neovascularization. Science 276, 1706-1709.

Strowski, M.Z., Kohler, M., Chen, H.Y., Trumbauer, M.E., Li, Z., Szalkowski, D., Gopal-Truter, S., Fisher, J.K., Schaeffer, J.M., Blake, A.D., Zhang, B.B., Wilkinson, H.A., 2003. Somatostatin receptor subtype 5 regulates insulin secretion and glucose homeostasis. Mol. Endocrinol. 17, 93-106.

Tallent, M.K., Dichter, M.A., Reisine, T., 1996. Evidence that a novel somatostatin receptor couples to an inward rectifier potassium current in AtT-20. Neuroscience. 73, $855-864$.

Tannenbaum, G.S., Epelbaum, J., 2000. Somatostatin In: Handbook of Physiology. Vol V, Section 7 : The Endocrine System, Hormonal Control of Growth. (J.L. Kostyo, Vol. Ed., H.M. Goodman, Section Ed.). Oxford University Press, NY, Oxford, pp.221-265. 
Thermos, K., Reisine, T., 1988. Somatostatin receptor subtypes in the clonal anterior pituitary cell lines AtT-20 and GH3. Mol. Pharmacol. 33, 370-377.

Thermos, K., He, H.-T., Wang, H-L., Margolis, N.,Reisine, T., 1989. Biochemical properties of brain somatostatin receptors. Neuroscience 31, 131-141.

Thermos, K., 2003. Functional mapping of somatostatin receptors in the retina: a review. Vision Res. 43, 1805-1815.

Thermos, K., Bagnoli, P., Epelbaum, J., Hoyer, D., 2006. The somatostatin sst $_{1}$ receptor: an autoreceptor for somatostatin in brain and retina? Pharmacol Ther. 110, $455-464$.

Tulipano, G., Soldi, D., Bagnasco, M., Culler, M.D., Taylor, J.E., Cocchi, D., Giustina, A., 2002. Characterization of new selective somatostatin receptor subtype-2 (sst2) antagonists, BIM-23627 and BIM-23454. Effects of BIM-23627 on GH release in anesthetized male rats after short-term high-dose dexamethasone treatment. Endocrinology. 143, 1218-1224.

Uemura, S., Pompolo, S., Furness, J.B., Hardy, K.J., 1997. Nitric oxide synthase in neurons of the human gall-bladder and its colocalization with neuropeptides. Gastroenterol. Hepatol. 12, 257-265.

Uretsky AD, Weiss BL, Yunker WK, Chang JP., 2003. Nitric oxide produced by a novel nitric oxide synthase isoform is necessary for gonadotropin-releasing hormoneinduced growth hormone secretion via a cGMP-dependent mechanism. J Neuroendocrinol. 15:667-76.

Vasilaki, A., Gardette, R., Epelbaum, J.,Thermos, K., 2001. NADPH-diaphorase colocalization with somatostatin receptor subtypes sst2A and sst2B in the retina. Invest. Ophthalmol. Vis. Sci. 42, 1600-1609. 
Vasilaki, A., Mouratidou, M., Schulz, S., Thermos, K., 2002. Somatostatin influences nitric oxide production in the rat retina. Neuropharmacology. 43, 899-909. Vasilaki, A., Georgoussi, Z., Thermos, K., 2003. Somatostatin receptors (sst 2 ) are coupled to Go and modulate GTPase activity in the rabbit retina. J. Neurochem. 84, $625-632$.

Vasilaki, A., Papadaki, T., Notas, G., Kolios, G., Mastrodimou, N., Hoyer, D., Tsilimbaris, M., Kouroumalis, E., Pallikaris, I., Thermos, K., 2004. Effect of somatostatin on nitric oxide production in human retinal pigment epithelium cell cultures. Invest. Ophthalmol. Vis. Sci. 45, 1499-1506.

Vincent, S.R., Johansson, O., 1983. Striatal neurons containing both somatostatinand avian pancreatic polypeptide (APP)-like immunoreactivities and NADPHdiaphorase activity: a light and electron microscopic study. J. Comp. Neurol. 217, 264-270.

Viollet, C., Vaillend, C., Videau, C., Bluet-Pajot, M.T,, Ungerer, A., L'Héritier, A., Kopp, C., Potier, B., Billard, J., Schaeffer, J., Smith, R.G., Rohrer, S.P., Wilkinson, H., Zheng, H., Epelbaum, J., 2000. Involvement of sst2 somatostatin receptor in locomotor, exploratory activity and emotional reactivity in mice. Eur. J. Neurosci. 12, $3761-3770$.

Wedel, B., Humbert, P., Harteneck, C., Foerster, J., Malkewitz, J., Böhme, E., Schultz, G., Koesling, D., 1994. Mutation of His-105 in the beta 1 subunit yields a nitric oxide-insensitive form of soluble guanylyl cyclase. Proc. Natl. Acad. Sci. (USA) 91, 2592-2596.

Wei, J.Y., Roy, D.S., Leconte, L., Barnstable, C.J., 1998. Molecular and pharmacological analysis of cyclic nucleotide-gated channel function in the central nervous system. Prog. Neurobiol. 56, 37-64. 
Yunker, W.K., Smith, S., Graves, C., Davis, P.J., Unniappan, S., Rivier, J.E., Peter, R.E., Chang, J.P., 2003. Endogenous hypothalamic somatostatins differentially regulate growth hormone secretion from goldfish pituitary somatotrophs in vitro. Endocrinology. 144, 4031-4041.

Zatelli, M.C., Piccin, D., Tagliati, F., Ambrosio, M.R., Margutti, A., Padovani, R, Scanarini, M., Culler, M.D., degli Uberti, E.C., 2003. Somatostatin receptor subtype 1 selective activation in human growth hormone (GH)- and prolactin (PRL)-secreting pituitary adenomas: effects on cell viability, GH, and PRL secretion. J. Clin. Endocrinol. Metab. 88, 2797-802.

Zech, J.C., Pouvreau, I., Cotinet,A., Goureau, O., Le Varlet, B., de Kozak, Y., 1998. Effect of cytokines and nitric oxide on tight junctions in cultured rat retinal pigment epithelium. Invest. Ophthalmol. Vis. Sci. 39, 1600-1608. 


\section{Figure Legends}

Figure 1. Mapping of ssts -NADPH-Diaphorase colocalization in the retina.

This figure depicts retinal neurons and the retinal pigment epithelium where the somatostatin receptor subtypes (black lined cell perimeter, dendrites and axons) were colocalized with NADPH-Diaphorase (dark gray fill). RPE, retinal pigment epithelium, ONL, outer nuclear layer, OPL, outer plexiform layer, INL, inner nuclear layer, IPL, inner plexiform layer, GCL, ganglion cell layer, R, rod, RBC, rod bipolar cell, C, cone, CBC, cone bipolar cell, V, vessel, AC, non-TH amacrine cell, GC, ganglion cell. Solid and dotted black lines indicate the presence and absence, respectively, of ssts in different cell bodies and/or processes.

Figure 2. Effect of somatostatin and specific analogs on the release of nitric oxide stable decomposition products $\mathrm{NO}_{\mathrm{x}}{ }^{-}$in retinal explants. A. Only somatostatin $(10 \mu \mathrm{M})$ and the $\mathrm{sst}_{2}$ specific analog L-779,976 $(10 \mu \mathrm{M})$ increased $\mathrm{NO}_{\mathrm{x}}{ }^{-}$release $\left({ }^{*} \mathrm{p}<0.05\right.$, $\left.{ }^{* *} \mathrm{p}<0.01\right)$. Other agonists: $\mathrm{sst}_{1}$ analog, $\mathrm{CH} 275, \mathrm{sst}_{3}$ analog, L-796,778, sst $_{4}$ analog, L-809,087, sst $_{5}$ analog, L-817-818.

B. L-779,976 increased $\mathrm{NO}_{\mathrm{x}}{ }^{-}$release in a statistically significant manner only at the concentration of $10 \mu \mathrm{M}(* * \mathrm{p}<0.01)$. [Modified from Vasilaki et al., 2002].

Figure 3: sst $_{2}$ activation increases cGMP basal levels in the retina. A. SRIF increased cGMP basal levels in rat retina in a concentration-dependent manner $(* * p<0.01)$. B. The $\mathrm{sst}_{2}$ receptor antagonist CYN-154806 $(1 \mu \mathrm{M})$ blocked SRIF's $(0.1 \mu \mathrm{M})$ actions. C. The sst $_{2}$ agonist lanreotide increased cGMP levels only at the concentration of $10 \mu \mathrm{M}$ (** $p<0.01)$. [Modified from Mastrodimou et al., 2006b]. 
Figure 4: Effect of NMMA and orthovanadate on SRIF-induced increase of cGMP levels. A. The nonselective NOS inhibitor NMMA $(250 \mu \mathrm{M})$ and the SHP-1 antagonist, orthovanadate $(1 \mu \mathrm{M})$, attenuated somatostatin's $(0.1 \mu \mathrm{M})$ mediated increase in cGMP levels. [**, \# $p<0.01]$. B. nNOS immunoreactivity was localized in cell bodies in the INL and GCL, as well as in processes in the IPL. No staining was observed in the absence of primary antibody (right panel). Scale bars: $20 \mu \mathrm{m}$. INL, inner nuclear layer, IPL, inner plexiform layer, GCL, ganglion cell layer. [Modified from Mastrodimou et al., 2006b]. 
sst1

sst2A

sst2B

NADPH-Diaphorase NADPH-Diaphorase NADPH-Diaphorase

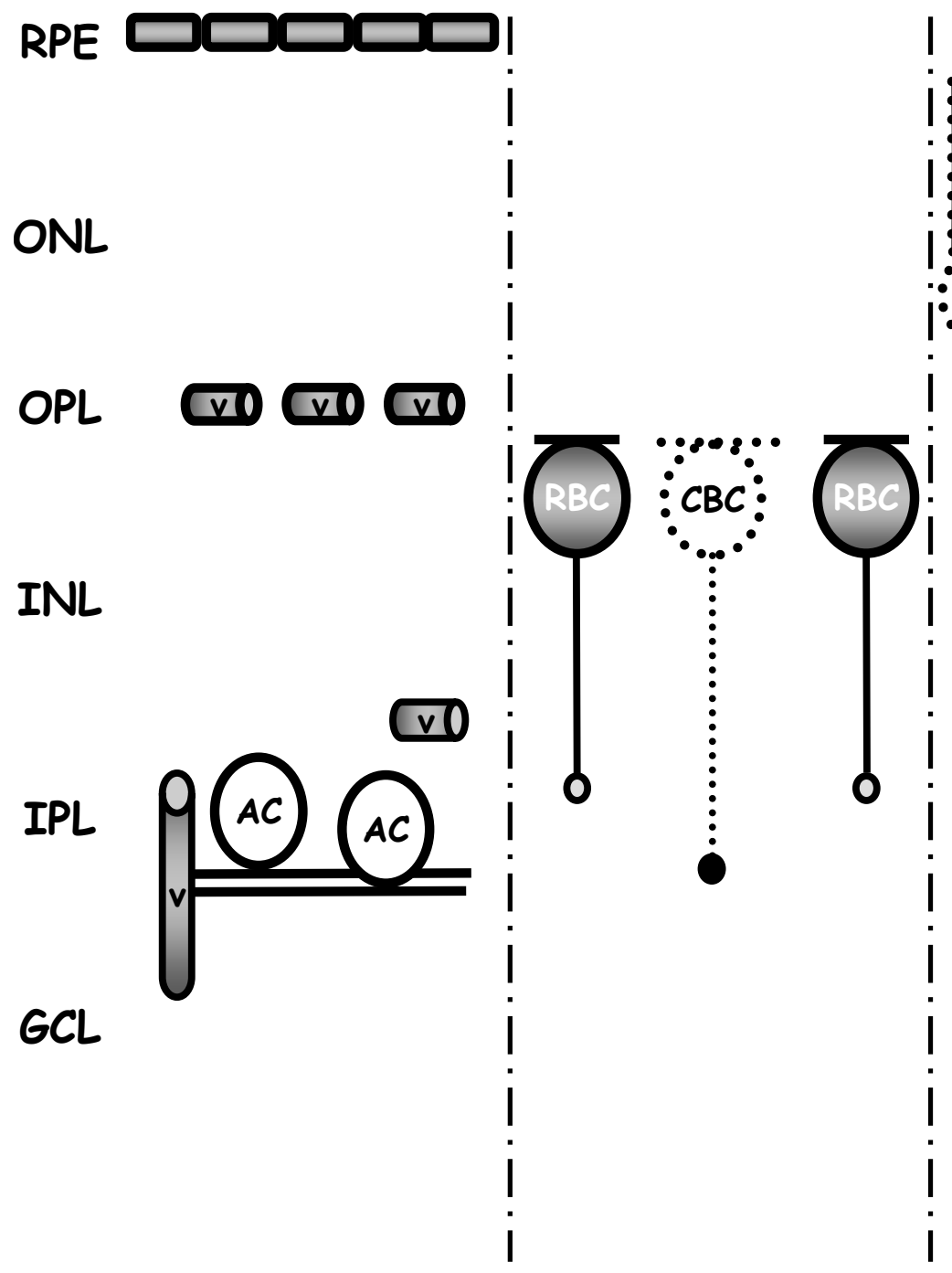

sst4

sst5

NADPH-Diaphorase NADPH-Diaphorase
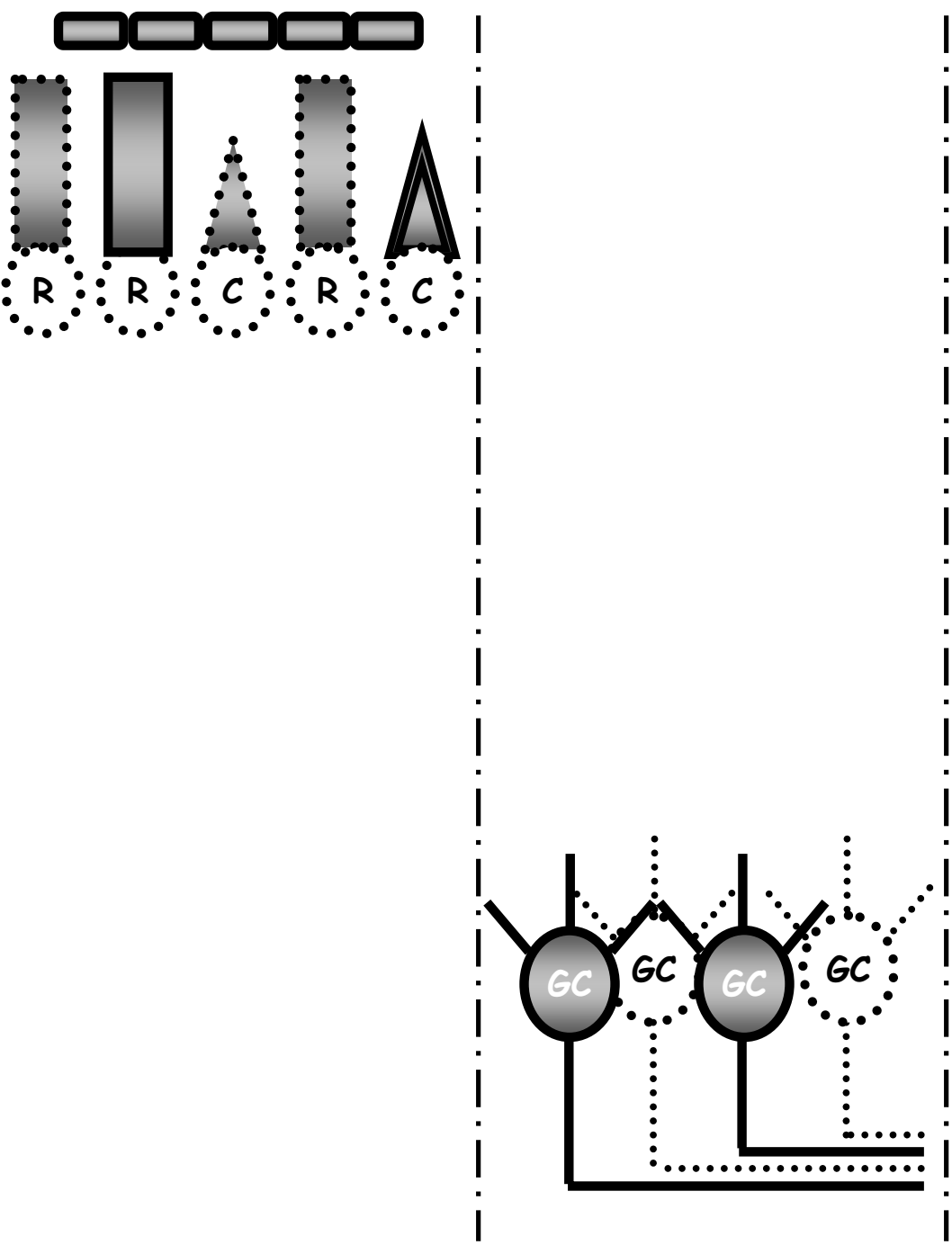

Figure 1 


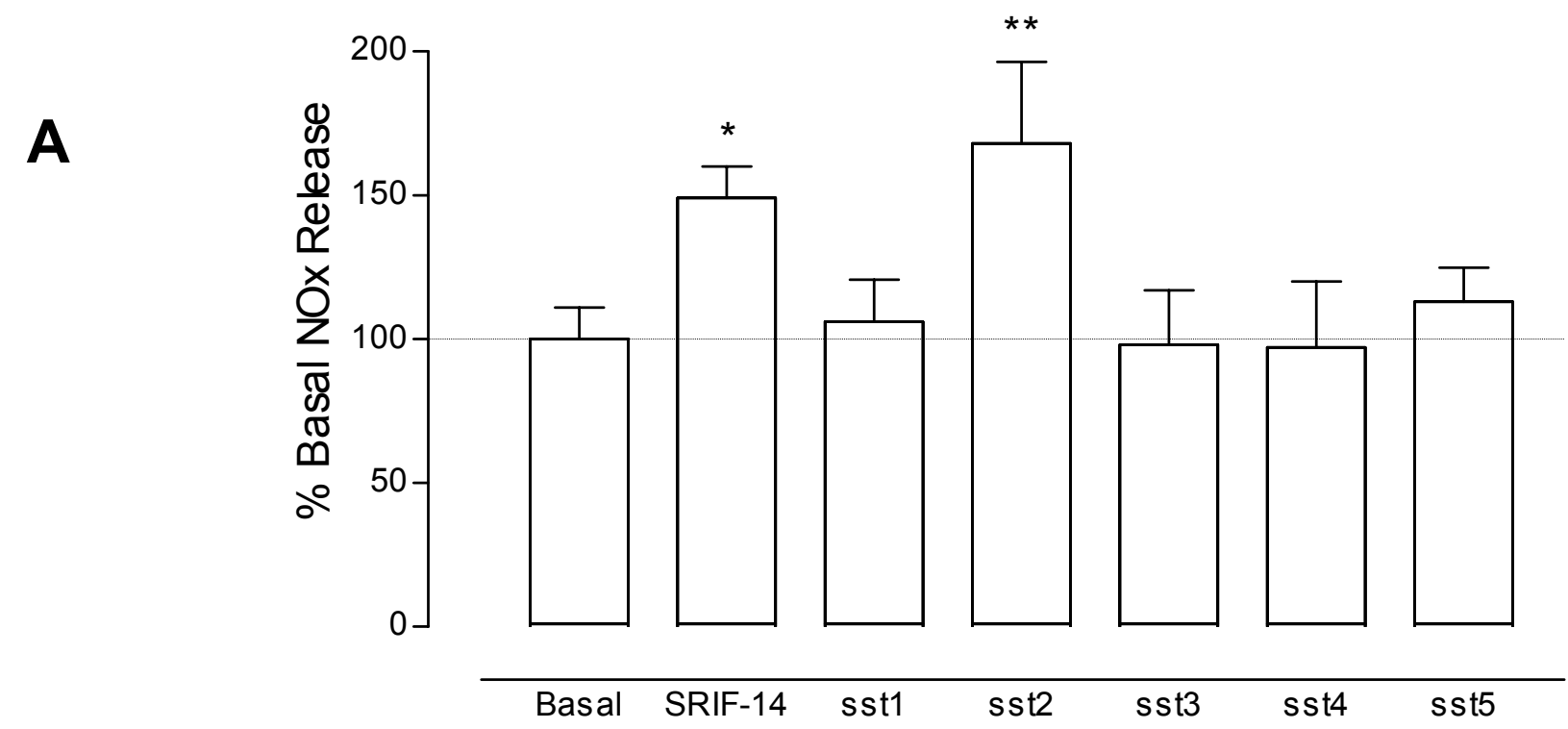

B

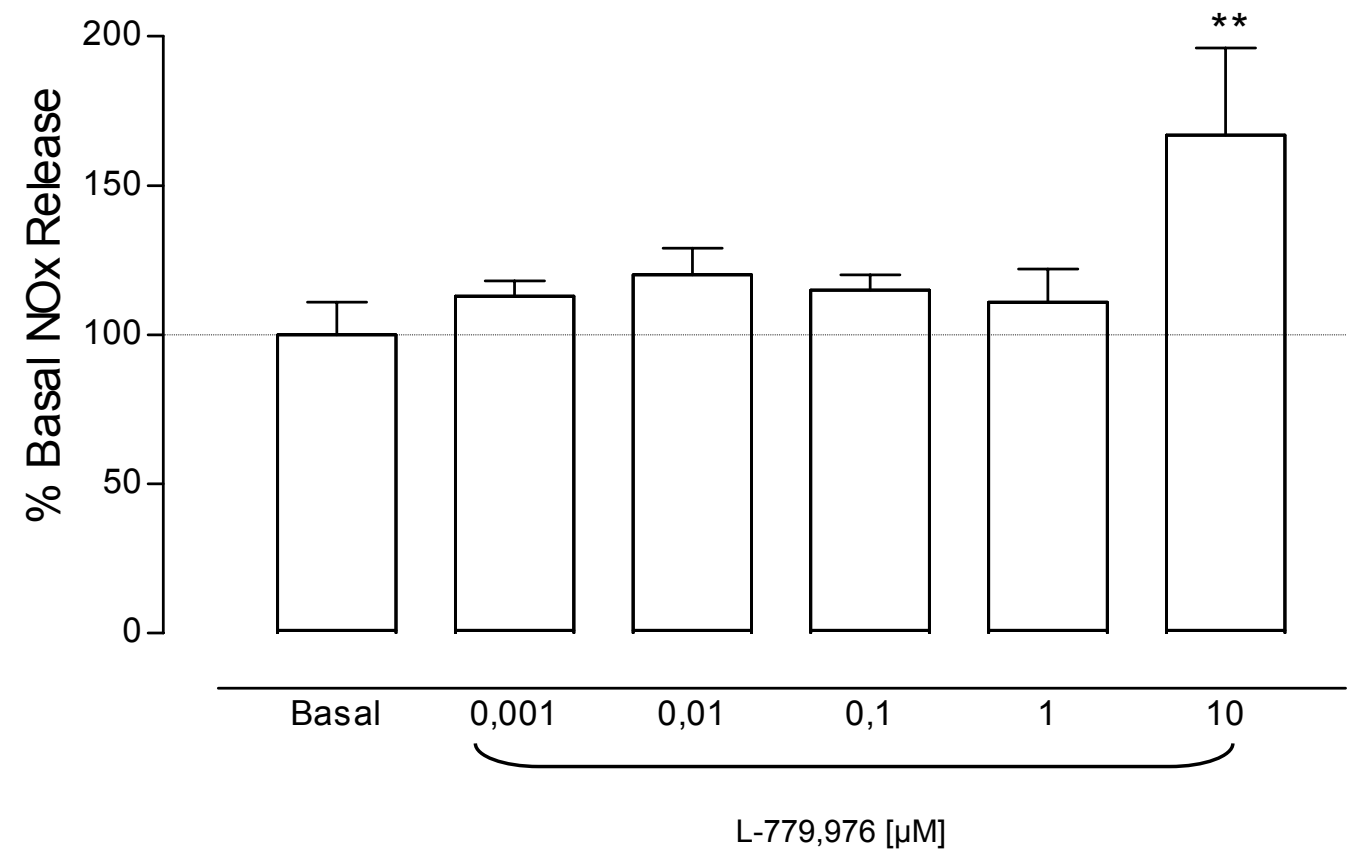

Figure 2

rage 38 ot 40 
A

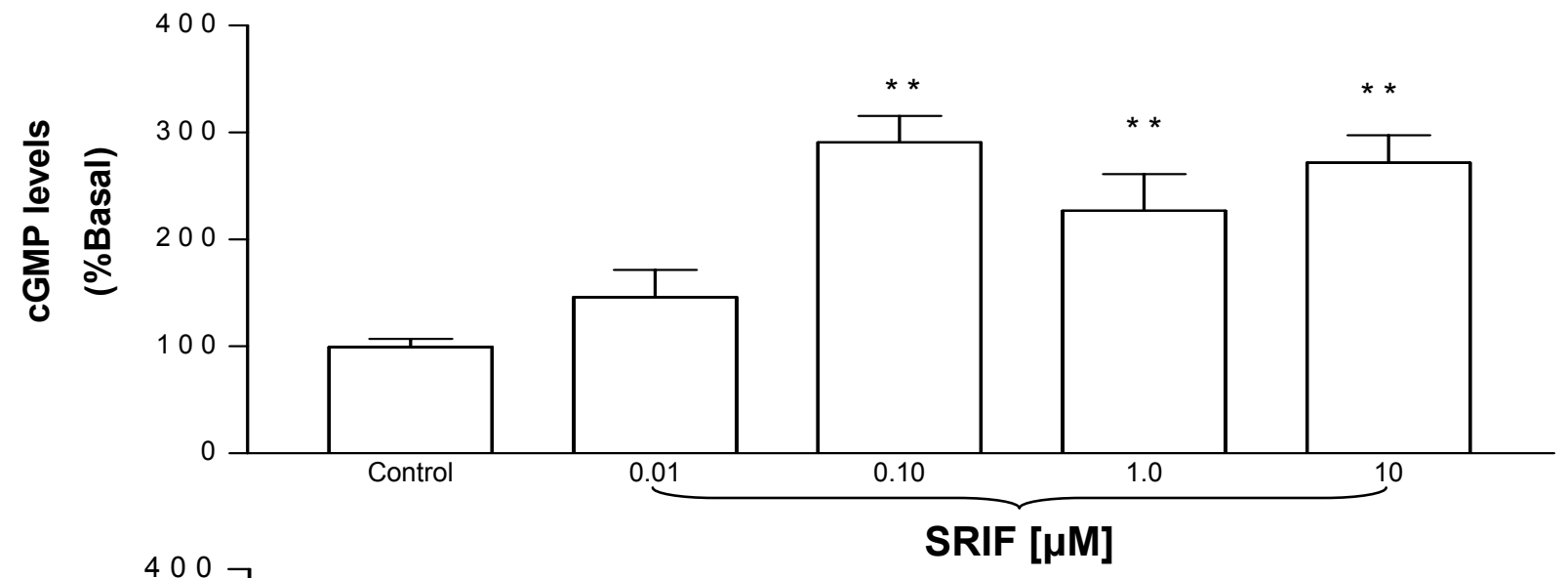

B

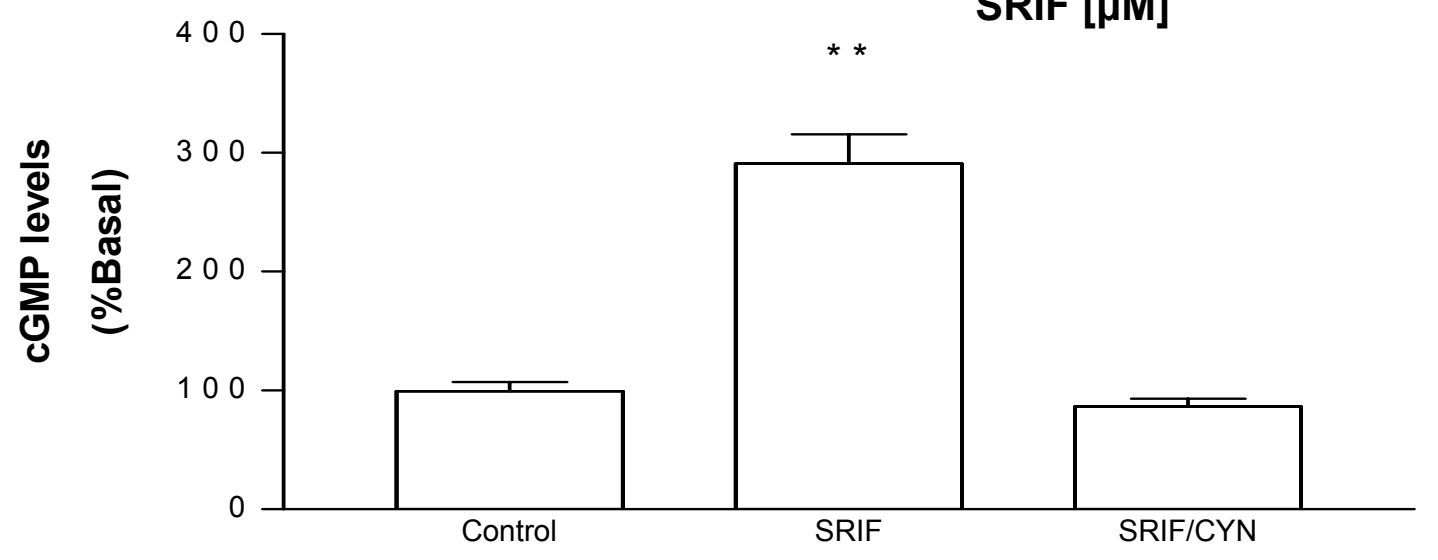

C

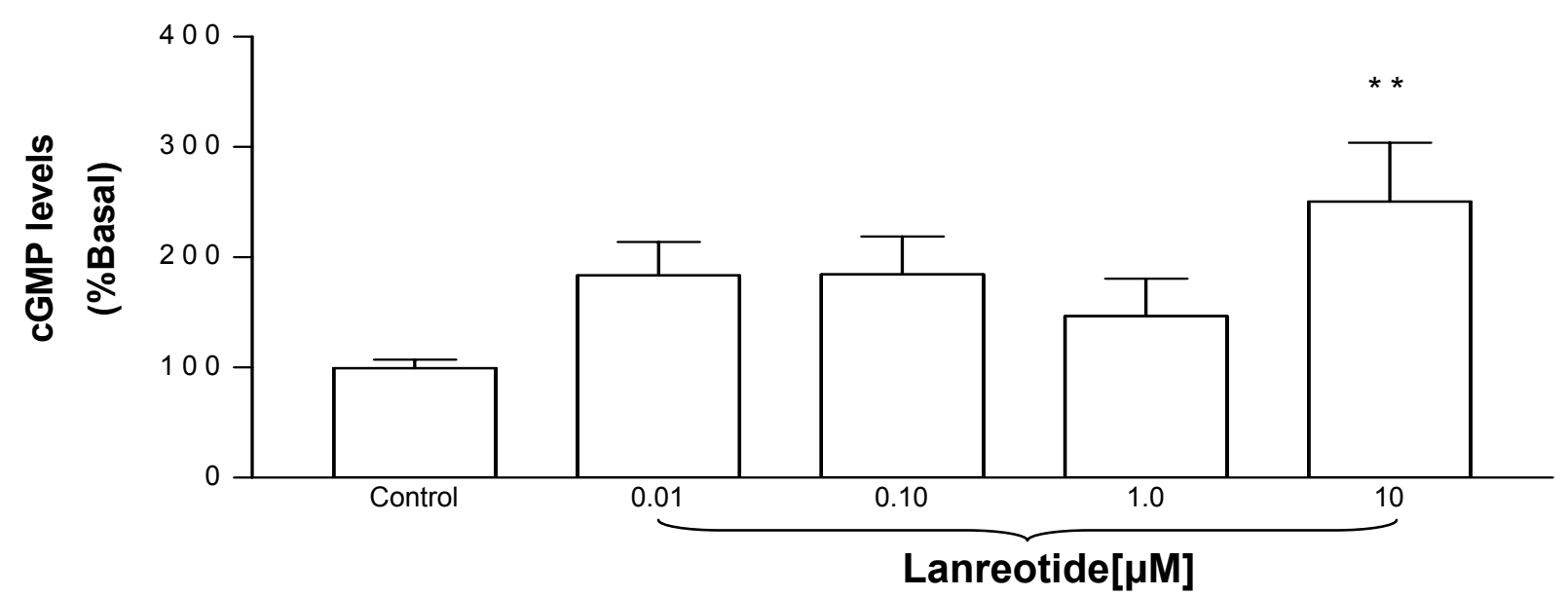

Figure 3 
A

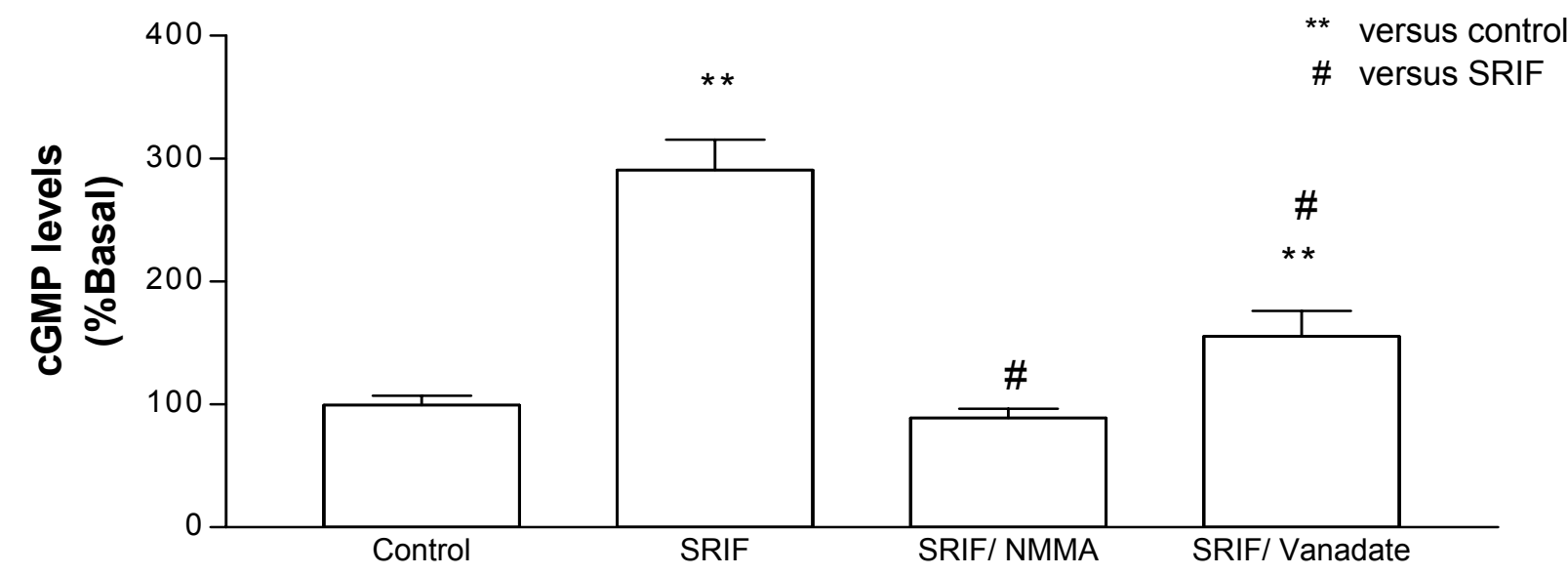

B
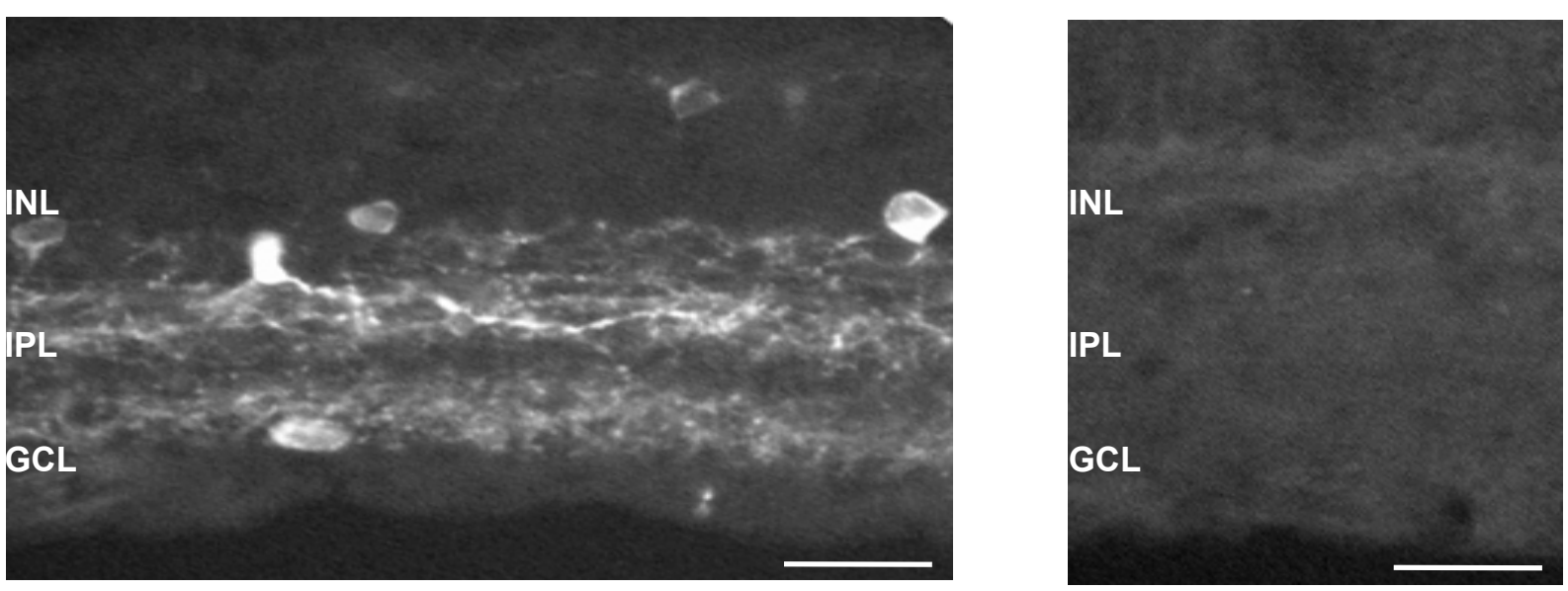

Figure 4 